\title{
BLACK BRANT RECORDS FROM WESTERN SASKATCHEWAN
}

\author{
by Alex Dzubin, Canadian Wildlife Service, Saskatoon \\ and Norm Hook, Department of Natural Resources, Kindersley
}

In North America, the Black Brant (Branta nigricans) of A.O.U. Checklist (1957), or (B. bernicla orientalis) of Delacour (1954), breeds in the western Arctic and migrates chiefly along the Pacific coast to winter from British Columbia to Baja California (Hellmayr and Conover, 1948; Delacour, op. cit.; Snyder, 1957; A.O.U., 1957; Barry, 1964; Einarson, 1965; Vaurie, 1965). It is primarily a marine goose, but inland records from California and Oregon on the wintering grounds are common. However, "inland records must be recognized as rare instances in these ranges" (Einarson, op. cit.). One unverified and three verified records from western Saskatchewan between 1961 and 1965 are therefore worthy of note; these follow:

1. Unverified sight record. One presumed adult, sex unknown, Sept. 18, 1961, Steeles Lake, three miles southeast of Major, Saskatchewan ( $51^{\circ} 50^{\prime}$ $\left.\mathrm{N}, 109^{\circ} 35^{\prime} \mathrm{W}\right)$. The bird was shot by hunters and described by a Saskatchewan Department of Natural Resources patrolman as a small dark goose having a black head, very black breast and belly, and very evident white neck ring. It was unlike some small Canada Geese (probably $B$. canadensis parvipes) taken at the same time. Two days after handling the bird the patrolman picked the picture of a Black Brant out of a field handbook.

2. Verified specimen-immature female. September 29, 1965, near Teo Lake, 10 miles west and 1 mile north of Kindersley, Saskatchewan $\left(51^{\circ} 30^{\prime}\right.$ $\left.\mathrm{N}, 109^{\circ} 25^{\prime} \mathrm{W}\right)$. The lone bird was shot by Mr. Ralph Gray of Kindersley, after it was attracted to a flock of 200 Canada Goose decoys in a wheatstubble field. Mr. Gray noted the distinctive call of the bird, much unlike any goose call he had heard previously. Later the same day (Septem- ber 29th) in a field one mile away, he again noted a similar lone brant calling within 100 yards of the decoys. He was unable to collect the second bird.

The specimen obtained is now in the collection of the Canadian Wildlife Service, Prairie Migratory Bird Research Centre, University of Saskatchewan Campus, Saskatoon, Saskatchewan. The weight and measurements of the specimen were as follows: culmen, $30 \mathrm{~mm}$; wing chord, 315 ; wing flat, 327; tarsus bone, 59; midtoe minus claw, 49; midtail, 90; total length, 518; weight 1016 grams.

3. Verified sight record. October 9, 1965 , at a marsh three miles south of Laporte, Saskatchewan $\left(51^{\circ} 10^{\prime} \mathrm{N}\right.$, $\left.109^{\circ} 30^{\prime} \mathrm{W}\right)$. Three hunters shot three immature White-fronted Geese (Anser albifrons), eight small Canada Geese, and an immature brant of unknown sex. The bird was checked by the junior author who noted that the belly was dark nearly to the rump and that only a barely discernible, partial white neck ring was evident.

4. Verified sight record. October 16 , 1965, near Cabri Lake, Saskatchewan $\left(51^{\circ} 05^{\prime} \mathrm{N}, 109^{\circ} 45^{\prime} \mathrm{W}\right)$. Again, a very dark-bellied, immature specimen of unknown sex which was the only goose shot by a party of six. We were unable to obtain the specimens mentioned in this and the previous item.

Only one previously published record of Black Brant is available from Saskatchewan. Nero (1956) recorded a full mount at the Swift Current Collegiate Museum. An immature bird, it was shot at Eston, Saskatchewan, on November 2, 1938 (Warren, 1956). Mitchell (1923) had earlier noted that there were no records of brant for the province.

Salt (1961) substantiated three records of brant for Alberta from 1957, 1959, and 1960. One was a Black Brant, one an im ature female 


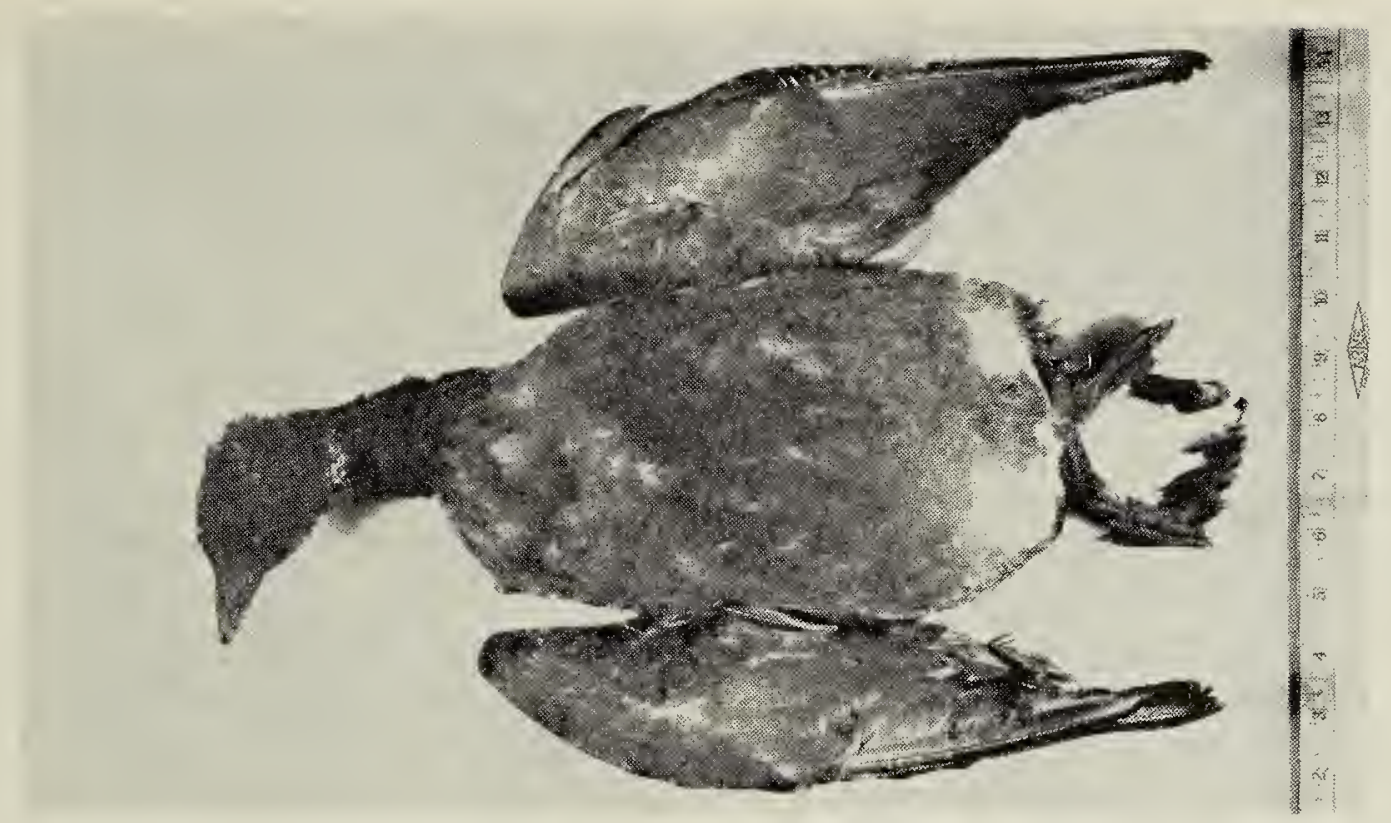

FIGURE 1-Ventral view of immature female Black Brant specimen from Saskatchewan. Scale in inches.

American Brant (B. bernicla hrota), and the third an apparent intergrade between the two. Portions of Alberta are also included in a "non-breeding range" of Back Brant by Delacour (1954:186). Taverner (1949) mentions one brant specimen for Manitoba but gives no other details. Hellmayr and Conover (1948) do not give an interior Canadian record of the Black Brant but show one record of the American Brant for North Dakota. They consider the American Brant a "very rare straggler to the interior of North America." Through the auspices of Dr. A. D. Geis, Assistant Director, Migratory Bird Population Station, U.S. Bureau of Sport Fisheries and Wildlife, Laurel, Maryland, I was able to examine the tail feathers of an immature brant (species unknown) shot by Mr. K. W. Knock of Bancroft, South Dakota, near the town of Willow Lake, on October 26, 1963. That record, plus another questionable brant tail specimen from North Dakota in 1963, are cited by A. Godin in U.S. Fish and Wildlife Service Administrative Report No. 73, dated July 16, 1965. Vaurie (1965) considered the Black Brant accidental in inland United States south to Texas. Hansen and Urban (1957) record several "aberrant" band recoveries of Alaskan banded birds, one from Colorado and another from Texas. Einarson (1965: 19) summarized the other inland records for North America but stressed the rarity of such occurrences. Other casual inland records for both forms are given in the A.O.U. Check-list (1957).

Cade (1953) presents records to show that there may be a major inland movement of brant through the Yukon River basin, but only in spring. A similar overland migration route is described by Barry (1964), for the American Brant between Hudson Bay and the Atlantic coast. Both short and long overflights of land masses by brant are also described in Siberia by Uspenski (1959), who noted that Black Brant breeding on the northern shore of the Chukotsk Peninsula and on Wrangel Island migrate across the Chukotsk Peninsula along river valleys to reach the south shore of the Gulf of Anadyr. Uspenski (1965) also showed the Asian migration route of $B$. $b$. orientalis as occurring along the interior rivers of the continent.

We can only speculate as to the origin of the Black Brant in western Saskatchewan. They may have originated at Point Barrow, Alaska, or at the mouth of the Mackenzie or Anderson Rivers, N.W.T. White-fronted Geese breeding in these three areas utilize the lakes of the Kindersley district during the autumn migration (Dzubin, Miller, and Schildman, 1964). A few brant stragglers could have mixed easily with migrating 
flocks of White-fronts. Hansen and Urban (1957) had previously suggested that two autumn brant recoveries, one from Colorado and the other from Texas, originated when brant from Alaska mixed with Whitefronted Goose flocks moving through the Central Flyway. Similarly, a small number of brant could have mixed with flocks of the small Canada Goose (B. c. parvipes) which breeds on Victoria Island and the Queen Maud Gulf lowlands (Snyder, 1957) and journeyed to western Saskatchewan with this subspecies. Each of the three verified records in 1965 was of an immature bird. These birds may have been forced inland by unseasonal Arctic storms and then continued on a southward, interior migration route instead of the traditional coastal route around Alaska.

Intensive field work on geese in central Alberta and Saskatchewan from 1960 to the present by provincial and federal wildlife personnel does not substantiate that any of the brant are regular or common autumn migrants in either province. Therefore, both the American and Black Brant should still be considered irregular, rare stragglers in the western Prairie Provinces.

We acknowledge gratefully the help of Dr. R. W. Nero, Division of Natural Sciences, University of Saskatchewan, Regina Campus, for bringing certain key references to our attention. Dr. F. G. Cooch, Canadian Wildlife Service, Ottawa, kindly provided a translated copy of Uspenski's book on Asian geese. Miss B. Davidson provided editorial aid.

There is still some question of the subspecific status of the Black Brant. We have followed the A.O.U. Checklist (1957). However, Delacour and Zimmer (1952) identify the Black Brant as Branta bernicla orientalis Tougarinov, a form also followed by Delacour (1954) and Scott (1957), who noted that $B . b$. nigricans bred to the northeast of Hudson Bay, wintered in New Jersey and is probably rare or possibly now extinct. The form which wintered on the North
American Pacific Coast was considered to be $B$. b. orientalis cf. Vaurie (1965) who used Branta (bernicla) nigricans to describe Black Brant.

Uspenski (1965) has most recently delineated the breeding grounds and migration routes of all brant in Asia. All are considered to be subspecies, $B$. b. hrota, bernicla, orientalis, and nigricans. $B . \quad b$. nigricans is shown breeding along the eastern mainland coast of Siberia, the New Siberian Islands, and on Wrangel Island where it is associated with $B$. b. orientalis, but generally breeding further east. $B$. b. nigricans is described as wintering along the Pacific Coast of North America while orientalis winters on the Yellow Sea, China.

\section{LITERATURE CITED}

American Ornithologists' Union. 1957. Checklist of North American birds. Fifth ed. Baltimore, $691 \mathrm{pp}$.

Barry, T. W. 1964. Waterfowl Tomorrow. Ed. J. Linduska, U.S.D.I., Washington, pp. 145 154.

Cade, T. J. 1953. Records of the Black Brant in the Yukon basin and the question of a spring migration route. J. Wildl. Mgmt., $19: 321-324$

Delacour, J. and J. T. Zimmer. 1952. The identity of Anser nigricans Lawrence, 1846. Auk, $69: 82-84$.

Delacour, J. 1954. Waterfowl of the world. Vol. I, Country Life, London.

Dzubin, A., H. Miller, and G. Schildman. 1964. Waterfowl Tomorrow. Ed. J. Linduska, U.S.D.I., Washington, pp. 135-143.

Einarsen, A. S. 1965. Black Brant: sea goose of the Pacific coast. Univ. Wash. Press, Seattle.

Hansen, H. A. and U. C. Nelson. 1957. Brant of the Bering Sea-migration and mortality. Trans. N. Amer. Wildl. Conf., 22 :237-256.

Hellmayr, C. E., and B. Conover. 1948. Catalogue of birds of the Americas. Field Mus. Nat. Hist. Vol. 23, Part I, No. 2, Chicago.

Mitchell, H. H. 1924. Birds of Saskatchewan. Canad. Field Nat., $38: 101-118$.

Nero, R. W. 1956. Black Brant specimen. Blue Jay, $14: 81-82$.

Salt, W. R. 1961. Recent additions to the avifauna of Alberta. Auk, 78:427-428.

Scott, P. 1957. A colored key to the wildfowl of the world. The Wildfowl Trust, Slimbridge.

Snyder, L. L. 1957. Arctic birds of Canada. Univ. Toronto Press, Toronto.

Taverner, P. A. 1949. Birds of Canada. The Musson Book Co., Toronto.

Uspenski, S. M. 1959. The brant goose (Branta bernicla L.) in the Soviet Union. The Wildfowl Trust Ann. Rept., $11: 80-93$.

Uspenski, S. M. 1965. Die Wildganse Nordeurasiens. Die Neue Brehm-Bucherei. A. Ziemsen, Verlag. Wittenberg (Translated by Canada Dept. of State through F. G. Cooch).

Vaurie, C. 1965. The birds of the Palearctic fauna. Non-passeriformes. H. F. and G. Witherby Ltd., London.

Warren, C. 1956. Black Brant. Blue Jay, 14 : 119. 